\title{
THE LIMITS OF LEGAL ACCOUNTABILITY OF THE EUROPEAN CENTRAL BANK
}

\author{
Marco Goldoni*
}

\section{INTRODUCTION}

This article will focus on the state of legal accountability in the relation between the European Court of Justice ("ECJ") and the European Central Bank ("ECB") as developed after the unfolding of the so-called Euro Crisis. The underlying hypothesis behind this analysis is twofold: the 2008 crisis has marked a remarkable change in the constitutional balance of the Eurozone, and as a consequence the constitutional function of the ECB has emerged and become visible.

To detect these changes, three cases will be discussed in order to show that there has been a shift in the ECJ's interpretation of the Treaty on the European Union ("TEU") and the Treaty on the Functioning of the European Union ("TFEU") ("the Treaties") ${ }^{1}$ and, accordingly, of the role of the ECB. The reaction to the Euro crisis has shown that the ECB cannot be deemed to be only an administrative independent agency, but it should be treated as an organ with constitutional functions, whose role has systemic implications for the stability of the European Union itself. ${ }^{2}$ Such recognition implies that the ECB's decisions ought to be treated not only procedurally, but in a genuinely political and constitutional way.

* Senior Lecturer, University of Glasgow School of Law. This paper was prepared for and first presented at the 8th Annual Transatlantic Law Forum, hosted by the Law \& Economics Center at George Mason University. The research for this article has been generously supported by subsidies for long-term conceptual development of the Institute of State and Law of the Academy of Sciences of the Czech Republic, v.v.i. (RVO: 68378122).

1 The Lisbon Treaty is the most recent rationalisation of the treaties that make up the European Union. European integration has been marked by a number of different treaties, which have been reduced to two. Unlike the previous structure of the Union, both treaties refer to the same legal subject. The "division into two European Treaties follows a functional criterion. While the (new) Treaty on the European Union contains the general provisions defining the Union, the Treaty on the Functioning of the European Union spells out specific provisions with regard to the Union institutions and politicies." ROBERT SCHÜTZE, EUROPEAN UNION LAW 37 (2015). For the sake of clarity, two points ought to be mentioned at the outset of this article: first, sometimes this article references the EC Treaty, which preceded the Lisbon Treaty. This is the case because some institutions and rules were already created by that Treaty. Second, other treaties have been recently approved in the wake of the Euro crisis, such as the European Stability Mechanism and the so-called Fiscal Compact. Neither are part of EU law, but they do apply to European institutions in certain circumstances.

2 See infra notes 48-56 and accompanying text. 
In a nutshell, the article pleads, first, for the recognition of the limits of legal accountability ${ }^{3}$ before the power-grabbing of the ECB and, second, for the opening of a constitutional discussion on the function of central banking. In order to prove this point, the next section explains why, in the context of the EU, and in particular after the 2008 crisis, the ECB has become an organ with a share in the European governing function. Hence, in the following three sections, the trajectory of the case law related to that role is illustrated and the limits of judicial review exposed. The last section briefly assesses the timid attitude of the ECJ before the ECB and mentions why this is a constitutional question. If the diagnosis is correct, then the prognosis is that a compensation scheme in the European balance of power with more political accountability of central banking will have to be introduced.

\section{THE ROLE OF THE EUROPEAN CENTRAL BANK IN THE EURO GOVERNANCE}

The rise of central banks as independent administrative agencies is undeniable and is the outcome of a revolutionary transformation in the conception of the constitutional organization of monetary and economic policies. ${ }^{4}$ Until the end of the seventies, in the Western world, there were only a few fully independent and autonomous central banks, the Bundesbank among them, for obvious historical reasons. ${ }^{5}$ But in order to cope with the increasing demand for a non-political government of monetary policy, and in the wake of the revival of monetarism, many Western states decided to disentangle their central banks from the relevant minister (usually, the treasury) ${ }^{6}$

The ECB is quintessentially a product, if not the epitome, of this widespread constitutional transformation. But, compared to other central banks, it operates in a rather different constitutional environment and on the basis of some different assumptions. ${ }^{7}$ The ECB is designed as a highly independent

3 On the difference between legal and political accountability, see Mark Bovens, Analysing and Assessing Accountability: A Conceptual Framework, 13 EUR. L.J. 447, 445-46 (2007).

4 Sam Y. Cross, Following the Bundesbank: The Spread of Central Bank Independence, 73 ForEIGN AFF. 128, 128-29, 131 (1994) (reviewing DAVID MARSH, THE Most POWERFUl BANK: INSIDE GERMANY's BUNDESBANK (1993)).

5 The control of inflation was deemed to be essential in order to avoid the rise of extremist political parties. The experience of the failure of the Weimar republic had suggested the detachment of monetary policy from governmental agencies, in favour of an autonomous and independent institution. See Christopher Alessi, Germany's Central Bank and the Eurozone, Council on Foreign Rel. (Feb. 7, 2013), http://www.cfr.org/world/germanys-central-bank-eurozone/p29934.

6 See KaArlo Tuori \& Klaus Tuori, The Eurozone Crisis: A Constitutional Analysis 222-23 (2014); Rosa Maria Lastra, The Independence of the European System of Central Banks, 33 HARV. INT'L L.J. 475, 477-78, 487-88 (1992) [hereinafter Lastra, Independence of European Central Banks].

7 Rosa M. Lastra, The Evolution of the European Central Bank, 35 FORDHAM INT'L L.J. 1260, 1260 (2012) [hereinafter Lastra, Evolution of the European Central Bank]. 
EU agency with a legal basis and detailed statutes on the level of the Treaties since the age of Maastricht. ${ }^{8}$ In theory, it operates like an administrative authority whose primary entrenched objective is price stability, ${ }^{9}$ but it is embedded in a wider constitutional framework which bestows upon it other important functions. ${ }^{10}$ Its independence is explicitly recognised by the TFEU:

When exercising the powers and carrying out the tasks and duties conferred upon them by the Treaties and the Statute of the [European System of Central Banks] and of the [ECB], neither the [ECB], nor a national central bank, nor any member of their decision-making bodies shall seek or take instructions from Union institutions, bodies, offices or agencies, from any government of a Member State or from any other body. ${ }^{11}$

The classic argument in support of strong independence is based the belief that:

central bankers, because of their specializations [and] relative insulation from political pressures, are more prepared than politicians to pursue the objective of price stability than politicians. The skills, expertise and superior qualifications of central bankers compared to politicians recommend an independent central bank, ... which may better guarantee a more objective, more "neutral" and faster decision-making process. $^{12}$

Legally, the argument is based on the recognition that the creation and regulation of the ECB's activities was not delegated to EU legislation - in which case, the ECB would have been a creature of statute-but directly by the Treaties and its protocols. ${ }^{13}$ The ECB's independence is also strengthened by another material factor: only the national central banks subscribe to its capital, and the ECB derives its revenues solely through its own monetary operations or through those of the national central banks operating within the European System of Central Banks ("ESCB"). ${ }^{14}$ Financially, the ECB does not depend on any other EU institutions. Even the status of its staff enjoys a remarkable independence when compared to other institutions. ${ }^{15}$

8 Id. at 1260-61; see also RenÉ SMits, THE EuROPEAN CENTRAL BANK IN THE EuROPEAN CONSTITUTIONAL ORDER 5-6 (2003).

9 Consolidated Version of the Treaty on the Functioning of the European Union art. 127(1), May 9, 2008, 2008 O.J. (C 115) 47 [hereinafter TFEU].

10 See Lastra, Independence of European Central Banks, supra note 7 at 1262-74 (describing the objectives and functions of the ECB).

11 TFEU art. 130

12 Lastra, Independence of European Central Banks, supra note 6, at 477.

13 See TUORI \& TUORI, supra note 6, at 223; ChiARA Zilioli \& MARTIN SELMAYr, THE LAW OF THE EUROPEAN CENTRAL BANK 32-33 (2001).

14 See Independence, EUR. CENT. BANK (last visited Feb. 24, 2017), https://www.ecb.europa.eu/ ecb/orga/independence/html/index.en.html.

15 See TFEU art. 130. 
The ECB's independence is explicitly recognised by the Treaties not only because of its competence, but also in a way functional to the realization of the Economic and Monetary Union ("EMU") as a currency union without federal devices of transfer or compensation schemes. ${ }^{16}$ In fact, the ECB independence from political pressure is basically necessary in order to maintain the separation between monetary policy, whose management is by now fully supranational, obviously only in the Eurozone, and economic policy, which is still driven by intergovernmental logic. ${ }^{17}$ The underlying argument is that the jurisdiction of an independent Central Bank ensures a coherent monetary policy not exposed to the pressure of short-term political interests. ${ }^{18}$ Functionally, the constitutional role of the ECB is made possible by the expertise of its members, which plays a key role when it comes to highly technical decisions on complicated questions of monetary policy. ${ }^{19}$ As a consequence of this setting, the ECB is isolated from any type of input legitimacy. ${ }^{20}$ Its credentials depend on its capacity to deliver outputs in a way that is credible and independent from stakeholders and politicians. ${ }^{21}$ The nature of this independence was not clear until the Euro entered Circulation. ${ }^{22}$ Some authors actually went as far as stating that the ECB and the ECSB enjoy an intrinsically autonomous constitutional status: essentially, a new supranational organization within the European Union. ${ }^{23}$ Given the expertise of the authors and the robust tradition of respect for central bank autonomy among academics, this position enjoyed considerable respect. ${ }^{24}$

The provisions not only circumscribe the objectives of monetary policy but also the instruments to pursue it to great detail. Following the logic of a currency union overseen by a technical body, the governance of the Euro is presented in the Treaties as being rule-based, which explains the amount of detailed regulation around monetary policy ${ }^{25}$ This is not only the outcome of

\footnotetext{
16 See How Economic and Monetary Union Works, EUR. COMM'N (last visited Feb. 24, 2017), http://ec.europa.eu/economy_finance/euro/emu/how/index_en.htm; see also DAVID HOWARTH \& PETER Loedel The European Central Bank: The New European Leviathan? 17-19 (2d ed. 2005).

17 See René Smits, The European Central Bank's Independence and Its Relations with Economic Policy Makers, 31 FORDHAM INT’L L.J. 1614, 1614-18 (2008).

18 Lastra, Independence of European Central Banks, supra note 6, at 477-78.

19 TUORI \& TUORI, supra note 6, at 30-31, 221-25 (explaining the rationales of the division between monetary and economic policy: one technical, one political).

20 Andrew Glencross, Democratic Inputs Versus Output-Oriented Governance: The ECB's Evolving Role and the New Architecture of Legitimacy in the EU, 5 J. INT'L ORGS. STUDS. 23, 24 (2014); see also FritZ W. SCHARPF, GOVERNING IN EUROPE: EFFECTIVE AND DEMOCRATIC? 6-11 (1999) (describing the distinction between input and output legitimacy).

21 Glencross, supra note 20, at 25-26.

22 See id. at 24.

23 See, e.g., ZILIOLI \& SELMAYR, supra note 13, at 29-35.

24 See SMITS, supra note 8, at 11 (explaining that Zilioli and Selmayr's view is one of the two main views of the ECB).

25 Alicia Hinarejos, The Euro Area Crisis in Constitutional Perspective 18-19 (2015).
} 
the concern of Germany, the Eurozone's reluctant hegemon: in fact, Germany feared that a relaxed fiscal policy of Southern Member States might have burdened, in the longer term, German savers. But this approach is also a way to ensure that the Euro governance's mechanisms, being managed according to rules, maintain a neutral character and remain within the realm of the rule of law. ${ }^{26}$ Otherwise, the whole project of the common currency would not be capable of generating a sufficient amount of mutual trust among the participating EU member states ("Member States") and it would collapse, eventually generating financial burdens for all Member States and in particular for those in the position of creditors. ${ }^{27}$

On a comparative note, such a strong constitutional definition of the principle of independence is rather exceptional. As already noted by Francis Snyder, the ECB enjoys "greater independence than the U.S. Federal Reserve Board and virtually all central banks prior to the Monetary Union." ${ }^{28}$ The U.S. Federal Reserve Board "does not enjoy constitutional status and, although it enjoys great independence by custom, nothing prevents Congress from adopting legislation mandating certain goals or policies . . ." ${ }^{29}$ Congress has rarely exercised this power, but nonetheless knows it can resort to in extreme circumstances. ${ }^{30}$ In Europe, both the Bank of England and the Netherlands Central Bank were renowned for their efficacious monetary control, even though each bank's functional independence was largely custombased, and could by bound by instructions from the Chancellor of the Exchequer or the Ministry of Finance. ${ }^{31}$

Contrary to the previous example, it is key to note that, in the context of the Eurozone, the construction of the single currency provided the ECB with a de facto governing power. ${ }^{32}$ Kenneth Dyson, in a prescient way, has detected the conditions which would make it possible for the ECB to become one of the key players in the Eurozone. ${ }^{33} \mathrm{He}$ calls this outcome an "ECBCentric Eurozone." ${ }^{34}$ Among the factors determining the rise of the ECB leadership the following should be mentioned: "A dominant economic policy paradigm of sound money and finance ... an 'asymmetric' [Economic and

\footnotetext{
26 See OtMAR ISSING, THE BIRTH OF THE EURO 191-94 (Nigel Hulbert trans., 2008).

27 Id.

28 Roger J. Goebel, Court of Justice Oversight Over the European Central Bank: Delimiting the ECB 's Constitutional Autonomy and Independence in the OLAF Judgment, 29 FORDHAM INT'L L.J. 610, 621 (2006) (citing Frances Snyder, EMU-Metaphor for European Union? Institutions, Rules and Types of Regulation, in EUROPE AFTER MAASTRICHT 63, 78 (Renaud Dehousse ed., 1994)).

29 Id.

30 See id.

31 Id.

32 See Zilioli \& SelmaYr, supra note 13, at 25-35 (contrasting the ECB's power and independence with that of other national banks and EU institutions).

33 See Kenneth Dyson, The Politics of the Eurozone: Stability or Breakdown? 11-12 (2000).

$34 I d$. at 12.
} 
Monetary Union] . . . the predominance of 'negative' over 'positive' integration ... and the issue of regime compatibility. ..." ${ }^{35}$

The asymmetric character of the Economic and Monetary Union ("EMU") has been explained as a necessary device in order to cope with prisoner's dilemma issues affecting the interaction among Member States. ${ }^{36}$ The core issue, in the case of the Euro, was that "of inducing credibility in others of one's commitment to the policy to be agreed to avoid defection from a mutually beneficial agreement. ${ }^{\prime 37}$ Because democratic competition works to create deficit financing, thereby undermining the long-term stability of the currency and public finances, it was thought that the Euro was designed to avoid forms of strong political accountability in the governance of the single currency. ${ }^{38}$ Key for this conclusion is the idea that the source of the Eurozone's distinctive character is its two-level nature: the EU and national levels are at once separate and interacting. ${ }^{39}$ This means that in terms of the governance of the Euro, the formal monopoly is in the hands of Euro-institutionsmostly, the ECB and the European Commission ("EC") — with no formal decision-making power left to the national level; yet, the decisions taken at the supranational level massively impact massively not only on the policies at the national level, but also on the fabric of national constitutions. ${ }^{40}$ The risk is that the stabilizing force of the Euro is limited to the goal of price stability, but at the expense of the solidity of Member States' political systems. ${ }^{41}$

In addition to the previous factors, one has to bear in mind the legal distinction between monetary and economic policies. In fact, even if it were possible to postulate that monetary and economic policies can play out separately in distinct channels - and this remain a debatable issue ${ }^{42}$ - the ECB

35 Id. at 11

36 Richard Bellamy \& Albert Weale, Political Legitimacy and European Monetary Union: Contracts, Constitutionalism and the Normative Logic of Two-Level Games, 22 J. EUR. PUB. POL'Y 257, 26162 (2015).

37 Id. at 261.

38 Id. at 261-62 (citing IssING, supra note 26, at 234-36).

39 Id. at 259, 263; see also How the European Union Works, EUR. UNION 3 (2012), http://eeas.europa.eu/archives/delegations/singapore/documents/more_info/eu_publications/how_the_european_union_works_en.pdf.

40 Bellamy \& Weale, supra note 36, at 262, 270; see also François Heisbourg, The EU Without the Euro, Survival Global Pol. \& Strategy, April/May 2014, at 27, 28-29; How Economic and Monetary Union Works, EUR. COMMISSION, http://ec.europa.eu/economy_finance/euro/emu/how/index _en.htm (last visited Feb. 24, 2017) (describing the rationale for maintaining closely coordinated, centralized and independent monetary control and the importance that member states coordinate economic and fiscal policies with common stability and growth objectives).

41 See, e.g., Heisbourg, supra note 40, at 28-29; Paul De Grauwe, Design Failures of the Eurozone, Vox (Sept. 7, 2015), http://voxeu.org/article/design-failures-eurozone.

42 Compare Hugo Dixon, Can Europe's Divided House Stand?: Separating Fiscal and Monetary Union, ForeIGN AFF., Nov./Dec. 2011, at 74, 74-76, with Ralph S. Musgrave, Monetary and Fiscal Policy Should be Merged, Which in Turn Changes the Role of Central Banks, 1-3 (Munich Pers. RePEc Archive, Paper No. 30521, 2011), https://mpra.ub.uni-muenchen.de/30521/1/MPRA_paper_30521.pdf. 
would still be in charge of determining the amount of credit to which the Member State and its banking system have access. ${ }^{43}$ The special position of the ECB - that is, it is beyond outside any clear State framework ${ }^{44}$ - gives to this institution an impact upon other European and Member States' institutions that is quite extraordinary in nature. ${ }^{45}$ One has to bear in mind that, even in the case of a Member State with an independent central bank, the main objectives are usually set by other institutions with more solid representative credentials. ${ }^{46}$ In this way, as was shown during the Greek crisis, the decisions of the ECB, for example, on liquidity, do shape, albeit indirectly, the policies of Member States. ${ }^{47}$

The new economic governance of the Euro has partially mutated and actually enhanced the role of the ECB in the constitutional framework of the Eurozone. ${ }^{48}$ The ECB is actively involved in the European Stability Mechanism ("ESM") as a member of the supervision team over the Member State's fiscal and financial policies to be implemented in compliance with conditions. ${ }^{49}$ The latter are a series of financial and economic constraints that apply to the Member State once its request to use the resources offered by the ESM is accepted. The rationale is that a loan is offered to the Member State in financial difficulty, but in order to avoid moral hazard, strict financial conditions are imposed upon its public spending. This new role entails that the $\mathrm{ECB}$, together with the Commission and the International Monetary Fund ("IMF"), and outside the framework of EU law, co-dictates certain policies and then supervises their application by the Member State subject to the program. ${ }^{50}$ Furthermore, the ECB has been given new tasks of supervision in the recently enacted European Banking Union. ${ }^{51}$ In a nutshell, as an organ (the

43 See, e.g., David McHugh, ECB Restores Bond Waiver, Lets Greek Banks Tap Credit, ASSOCIATED PRESS (June 22, 2016), http://bigstory.ap.org/article/1ddb37c548c84e0391df8cec 02b49e0a/ecb-restores-bond-waiver-lets-greek-banks-tap-credit; Landon Thomas, Jr., European Central Bank Squeezes Greek Banks, Tightening Access to Loans, N.Y. TIMES (April 21, 2015), http://www.nytimes.com/2015/04/22/business/dealbook/ecb-tightens-flow-of-money-to-greek-banks.html?_r=0.

44 Christoph S. Weber \& Benedikt Forschner, ECB: Independence at Risk?, 49 INTERECONOMICS 45,48 (2014).

45 See, e.g., R.A., The Euro Crisis: Rule by Technocracy, THE ECONOMIST: FREE EXCHANGE (Nov. 17, 2011, 4:28 PM), http://www.economist.com/blogs/freeexchange/2011/11/euro-crisis-13; Simon Nixon, The ECB Power Base Grows Ever Stronger, WALl ST. J. (Eur. ED.) (Feb. 27, 2012).

46 See Smits, supra note 17, at 1625; David S. D’Amato, How Independent are Central Banks?, INST. ECON. AFF. (May 31, 2013), https://iea.org.uk/blog/how-independent-are-central-banks.

47 See Nixon, supra note 45.

48 See generally Treaty Establishing the European Stability Mechanism, Feb. 2, 2012, T/ESM 2012 LT/en 1, http://www.esm.europa.eu/about/legal-documents/ESM\%20 Treaty.htm [hereinafter ESM Treaty].

49 Id. art. 5.

50 Id. art. 13.

51 Bernd Krauskopf, et al., Some Critical Aspects of the European Banking Union, 29 BANKING \& FIN. L. REV. 241, 242-44 (2014); Understanding . . Banking Union, EUR. COMM'N: BANKING \& FIN. NEWSLETTER 2 (Feb. 27, 2015), http://ec.europa.eu/newsroom/fisma/itemdetail.cfm?item 
ECB) and as a function (as central banking), the ECB co-determines the political direction of the Eurozone. ${ }^{52}$ In constitutional parlance, this means that the ECB performs a governing function. ${ }^{53}$ As such, its status as a materially constitutional organ ought to be recognized and its political salience too. Unsurprisingly, a series of suits provided the ECJ the chance to send a signal to the European political process that such a transformation ought to be discussed in and by the public. ${ }^{54}$ Unfortunately, the ECJ shied away and showed an unduly, yet predictable, deference toward the policies of the ECB. ${ }^{55}$ The outcome of the recent decisions is to strengthen the solidity of the emergency regime created to tackle the Euro crisis ${ }^{56}$ Far from being temporary in nature, the enhanced role of the ECB will have to be addressed at the level of constitutional design.

\section{OLAF: RESISTING THE POWER-GRABBING OF THE ECB}

The nature of the ECB's independence, already subject to academic analysis, ${ }^{57}$ was tested in an influential case decided in 2003 by the ECJ, which addressed a confrontation between the European Commission and the ECB on the extent of powers of the newly instituted Office Lutte Anit-Fraud ("OLAF"). ${ }^{58}$ OLAF is the European Anti-Fraud Office; it was created in the aftermath of the resignation of the Santer's Commission for corruption, ${ }^{59}$ with the task of examining all illegal activities which are detrimental to the EU

$\mathrm{id}=20758 \&$ newsletter_id=166\&utm_source=fisma_newsletter\&utm_medium $=$ email\&utm_cam-

paign $=$ Finance $\% 20 \& u$ tm_content $=$ Understanding...\%20Banking\%20Union\&lang=en.

52 See René Smits, The Crisis Response in Europe's Economic and Monetary Union: Overview of Legal Developments, 38 FORDHAM INT'L L J. 1135, 1175 (2015); The Politicisation of the European Central Bank, EuRopeAn UNION CTR. OF THE UNIV. OF N.C. AT CHAPEL HiLl: EU BRIEFINGS (July 30, 2013), http://europe.unc.edu/wp-content/uploads/2013/12/Brief1312-ecb.pdf (last visited Feb. 25, 2017); see also Nina Werkhäuser, DW Survey: Who Holds the Most Sway in the EU?, DW.COM (Aug. 24, 2015), http://www.dw.com/en/dw-survey-who-holds-the-most-sway-in-the-eu/a-18668061 (finding that 39\% of those surveyed believed the ECB has the greatest influence on political direction in the EU).

53 Hans Keman, Constitutional Government in 1 GOV'T AND POL. 68, 69 (Masashi Sekiguchi ed., 2009).

54 Case C-62/14, Gauweiler v. Deutscher Bundestag, ECLI:EU:C:2015:400 (E.C.J.); Case C370/12, Pringle v. Gov’t of Ireland, ECLI:EU:C:2012:756 (E.C.J.).

55 Gauweiler, ECLI:EU:C:2015:400, ๆ 55-56, 92, 127; Pringle, ECLI:EU:C:2012: 756, ๆ 60$62,154-165$.

56 For a brilliant analysis of the long-term impact of the Euro emergency regime, see generally Jonathan White, Authority After Emergency Rule, 78 MODERN L. REV. 585 (2015).

57 For example, Fabian Amtenbrink has analysed the ECB's independence under its institutional, functional, organizational and financial aspects. FABIAN AMTENBRINK, THE DEMOCRATIC ACCOUNTABILITY OF CENTRAL BANKS: A COMPARATIVE STUDY OF THE EUROPEAN CENTRAL BANK 1822 (1999).

58 Case C-11/00, Comm'n of the European Cmtys. v. European Cent. Bank, 2003 E.C.R. I-7147.

59 For a thorough description of the Santer's Commission, see Adam Tomkins, Responsibility and Resignation in the European Commission, 62 MODERN L. REV. 744 (1999). 
financial interests. ${ }^{60}$ Despite being formally part of the European Commission, it enjoys a high level of autonomy and independence. ${ }^{61}$ The case was seminal for several reasons, but one in particular must be highlighted for the purposes of this article. The ECB's line of defense was based on the argument that the nature of its institutional independence was of a constitutional nature; hence, the protection of its autonomy and independence ought to be the highest. $^{62}$

Note that here the constitutional nature of the ECB's independence meant legal entrenchment. ${ }^{63}$ The core of the ECB's claim went so far as to state that it should not be deemed to be simply an organ within (what was then) the EC, and had a legal personality distinct from the EC. ${ }^{64}$ The idea, advocated by Zilioli and Selmayr, of an ECB as a supranational organization is usually based on the recognition of the legal source behind its creation. ${ }^{65}$ In the case of the ECB, its institution and granting of powers and duties come from the Member States' ratification of the Maastricht Treaty and not from ordinary Community legislation. ${ }^{66}$ The Maastricht Treaty would have separated the position of the ECB not only in terms of its function, but even in terms of its full autonomy: "the ECB is also not institutionally linked to the Communities, ... [and] it never acts as financial instrument of the Community institutions or even for and on behalf of them . . . as this would be incompatible both with its independence and with its primary objective of price stability. ${ }^{97}$ Moreover, the ECB budget, financial resources and expenses are totally autonomous, based upon grants of power under the EC Treaty or the Protocol on the Statute of the ESCB and ECB.$^{68}$ The ECB noted also that it was granted the right to independently set its internal organization procedures and staff rules, which would also include internal controls against fraud and corruption. ${ }^{69}$ In light of these points, and on a comparative scale, it is reasonable to affirm that the ECB enjoys an autonomy and independence that go much further than any historical precedent. ${ }^{70}$

\footnotetext{
60 For an in-depth analysis of this body, see generally J.F.H. INGHELRAM, LEGAL AND INSTITUTIONAL ASPECTS OF THE EUROPEAN ANTI-FRAUD OFFICE (OLAF): AN ANALYSIS With A LOOK ForWARD to A EUROPEAN PUBLIC PROSECUTOR'S OFFICE (2011).

61 Goebel, supra note 28, at 629 (citing Commission Decision (EC) of 28 April 1999, Establishing the European Anti-Fraud Office (OLAF) 1999 O.J. (L 136) 20).

62 Case C-11/00, European Cent. Bank, 2003 E.C.R. at I-7246-48, 51-52.

$63 I d$. at I-7265-66.

64 See id. at I-7264; Hanspeter K. SCheller, The European Central BanK: History, Role AND FUNCTIONS 43 (2004).

65 ZiLIOLI \& SELMAYR, supra note 13, at 12.

66 Id. at $30-31$.

$67 I d$. at 30 .

68 Id. at $29-31$.

69 Case C-11/00, Comm'n of the European Cmtys. v. European Cent. Bank, 2003 E.C.R. I-7215, I7260.

70 ZILIOLI \& SELMAYR, supra note 13, at 32-33. For academic reactions against this argument, see generally Fabian Amtenbrink \& Jakob deHaan, The European Central Bank: An Independent Specialized
} 
The question submitted to the Court concerned the ECB's Decision $1999 / 726,{ }^{71}$ creating its own internal procedures to combat fraud. According to the Commission, this ECB decision violated the rules of Regulation $1073 / 1999,{ }^{72}$ which authorised OLAF to exercise its investigative powers in internal reviews of all EC institutions, agencies, and bodies. ${ }^{73}$ By delegating its own antifraud powers to an independent agency like OLAF, the Commission hoped to improve the fight against fraud, corruption and other illegal activities. ${ }^{74}$ The problem is that, from the perspective of the ECB, the latter autonomous status and effective functioning in shaping monetary policies, might be jeopardized if subjected to external (even though independent) investigations..$^{75}$ As a matter of constitutional balance, the argument stated that the inter-institutional equilibrium among EU institutions would have been shaken in a negative way for the ECB in case of an "intrusion" by an administrative agency. ${ }^{76} \mathrm{On}$ the basis of its claim of constitutional nature, the ECB maintained, against the Commission, that the regulation did not apply to it. ${ }^{77}$

In adjudicating this inter-institutional conflict, an issue on which the Court has always proved to be particularly careful, the ECJ had to face the first attempt at power-grabbing by the ECB. ${ }^{78}$ The ECJ, in an assertive and non-deferential way, rejected the view that the ECB could be considered an autonomous order among other orders. ${ }^{79}$ The Advocate General rejected the arguments made by the ECB in his highly detailed opinion:

The ECB is subject to the general principles of laws which form part of [EC] law and promotes the goals of the [EC] set out in Article 2 of the EC [as it was codified before the Lisbon Treaty] though the implementation of the tasks and duties laid upon it. It may therefore be described as the Central Bank of the [EC]; it would be inaccurate to characterise it, as have some writers, as an organization which is 'independent of the [EC],' a 'Community within the Community,' a 'new Community,'

\footnotetext{
Organization of Community Law - A Comment, 39 COMmon MKT. L. Rev. 65 (2002); Ramon Torrent, Whom is the European Central Bank the Central Bank Of?: Reaction to Zilioli and Selmayr, 36 CommoN MKT. L. REV. 1229 (1999).

71 European Central Bank Decision No. 1999/726/EC, O.J. L 291, at 36 (1999).

72 Commission Regulation 1073/1999, Concerning Investigations conducted by the European AntiFraud Office (OLAF) 1999 O.J. (L 136) 1 (E.C.).

73 Case C-11/00, European Cent. Bank, 2003 E.C.R. at I-7217, 7239-43; see also LIBER AMICORUM \& Paolo Zamboni Garavelli, Legal Aspects of the European System of Central Banks 32 33 (2005).

74 European Cent. Bank, 2003 E.C.R. at I-7223-24 (citing Commission Decision (E.C.) of 28 April 1999, art. 2, 1999 O.J. (L 136/20) 21).

75 Id. at I-7259-60.

76 Id. at I-7276; see also Goebel, supra note 28, at 628.

77 European Cent. Bank, 2003 E.C.R. at I-7245-46.

78 Goebel, supra note 28, at 627 (2006).

79 European Cent. Bank, 2003 E.C.R. at I-7265.
} 
or, indeed, as something falling outside the notion of a body established by, or on the basis of, the EC Treaty in Regulation No. 1073/1999. ${ }^{80}$

The Court followed the Advocate General's opinion, stating that the ECB, by being created by the EC Treaty, was to be granted a high level of independence but should still be considered an organ of the EC and as such, to be subject to the OLAF regulation. ${ }^{81}$ The main justification behind this decision was determined by a functional interpretation of the ECB's independence:

$[T]$ he independence thus established is not an end in itself; it serves a specific purpose. By shielding the decision-making process of the ECB from short-term political pressures the principle of independence aims to enable the ECB effectively to pursue the aim of price stability and, without prejudice to that aim, support the economic policies of the Community. ${ }^{82}$

In other words, the Advocate General drew a functional boundary for the ECB's independence: the interference with the ECB that the Treaty forbids is limited to those activities liable to undermine the ability of the ECB to deliver price stability. ${ }^{83}$ Beyond this realm, other interactions or reviews are actually legitimate. ${ }^{84}$ The ECJ followed the same line of reasoning, stating that the ECB's independence is "strictly functional and is limited to the performance of [its] specific tasks." ${ }^{" 85}$ More specifically, the Court stated that the ECB's independence did not mean complete absence of control over its activities. ${ }^{86}$ In fact, "the ECB is, on the conditions laid down by the EC Treaty and the ESCB Statute, subject to various kinds of [EC] controls, notably review by the Court of Justice and control by the Court of Auditors." ${ }^{\prime 87}$

80 Opinion of Advocate General Jacobs, Case C-11/00, Comm'n of the European Cmtys. v. European Cent. Bank, 2003 E.C.R. I-7155, I-7175 (footnotes omitted).

81 European Cent. Bank, 2003 E.C.R. at I-7265; Opinion of Advocate General Jacobs, European Cent. Bank, 2003 E.C.R. at I-7202 ("As is evident . . ., the Treaty and the Statute confer upon the ECB a high level of independence which is equivalent to, or perhaps greater than, the independence of the national central banks which prevailed prior to the reforms undertaken at national level in order to comply with the requirements for entry into the Monetary Union. However, the principle of independence does not imply a total isolation from, or a complete absence of cooperation with, the institutions and bodies of the Community. The Treaty prohibits only influence which is liable to undermine the ability of the ECB to carry out its tasks effectively with a view to price stability, and which must therefore be regarded as undue.") (footnotes omitted).

82 Opinion of Advocate General Jacobs, European Cent. Bank, 2003 E.C.R. at I-7200.

83 Id. at I-7202. Note that even the definition of price stability, absent from the Treaties, has been left to the ECB. The Definition of Price Stability, EuR. CENT. BANK, https://www.ecb. europa.eu/mopo/strategy/pricestab/html/index.en.html (last visited Feb. 25, 2017) (explaining that the ECB's Governing Council has defined price stability as "a year-on-year increase in the Harmonised Index of Consumer Prices (HICP) for the euro area below $2 \%$.").

84 Opinion of Advocate General Jacobs, European Cent. Bank, 2003 E.C.R. at I-7202.

85 European Cent. Bank, 2003 E.C.R. at I-7263.

86 Id.

87 Id. at I-7265. 
In this decision, the ECJ basically rebutted the ECB's attempt to expand its independence in a way completely unrelated to its functions. ${ }^{88}$ In this way, the ECJ defined both the nature of the ECB and its constitutional role. The Advocate General even went as far as discussing the necessary elements of democratic accountability which had to be respected by the ECB, even though this kind of accountability was basically reduced to the participation, without right to vote, of the President of the Council of the European Union and of the accountability owned to the European Parliament in the form of reports and questioning before the latter's committees. ${ }^{89}$ However, the decision occurred at the outset of the governance of the Eurozone and is still far removed from the first signs of the incipient economic and financial crises. ${ }^{90}$ What might have seemed an assertion of judicial activism and a defeat for the ECB was reverted a few years later when the ECJ had to decide on ECB's competences in a global context where the functions of central banking were again being discussed.

\section{PRINGLE: From RULE-BASED to Policy-BASED GOVERNANCE}

Crucial to the understanding of the new challenges faced by the ECJ is the change in central banking practices and thinking that occurred after the 2008 Euro Crisis. ${ }^{91}$ Fear of catastrophic meltdown from contagious debts drew central banks, directly or indirectly, into monetizing public debt. ${ }^{92}$ Both the Bank of England and the U.S. Federal Reserve Bank resorted to programs of quantitative easing. " "They sought to inject liquidity and to reduce longterm interest rates by purchasing government bonds." for example, acquired government bonds up to almost 10 percent of GDP. ${ }^{95}$

The ECB was facing the same type of systemic pressure but in a completely different constitutional and administrative system. ${ }^{96}$ The self-perception of the role of the ECB partially changed as a reaction to the crisis, but its

\footnotetext{
88 Goebel, supra note 28 , at 642-43.

89 Opinion of Advocate General Jacobs, European Cent. Bank, 2003 E.C.R. at I-7203; Goebel, supra note 28 , at 639 .

90 See Howard Davies \& David Green, Banking on the Future: The Fall and Rise of Central Banking 1 (2010).

91 Id. at 52.

92 KenNeth Dyson, States, DebT, AND POWER: 'SAints' and ‘SinNERS' in EUROPEAN History AND INTEGRATION 386 (2014).

93 Id.

94 Id.

95 Id.

96 Id.
} 
activities had to find a way to ground legitimacy and legality in the Treaties. ${ }^{97}$ The ECB proceeded by stealth in re-financing both national banking systems and governments through enhanced credit provisions to banks. ${ }^{98}$ Furthermore, in order to stabilize market expectations, the ECB, during the years 2011-2012, embraced a new role, committing itself to unlimited, but conditional, intervention in sovereign bond secondary markets, despite the strong and public opposition of the Bundesbank. ${ }^{99}$ Starting in May 2010, the ECB agreed to limited sovereign bond purchases as part of the larger Eurozone bail-out package, raising many concerns in terms of the legality and longterm consequences of this move. ${ }^{100}$ It also agreed to be an active part of the new economic governance of the Eurozone, by taking part in the oversight of institutions introduced by the European Stability Mechanism ("ESM") and acting as the site for the Single Supervisory Mechanism at the heart of the projected European banking union. ${ }^{101}$ Finally, after having abandoned the temporary and circumscribed project of limited buying on the secondary markets of bonds issued by debtor States, the ECB launched the infamous Outright Monetary Transactions ("OMT") program, on which more will be said in the following section. ${ }^{102}$ All these new instruments conjure up a substantial transformation of the role of the ECB and a change of the constitutional balance within the EU. ${ }^{103}$

By now, the legitimacy of the ECB's position in the Euro crisis has been judicially tested twice. ${ }^{104}$ In 2012, the first seminal case, Pringle, ${ }^{105}$ was brought before the ECJ by a preliminary reference coming from the Irish $\mathrm{Su}-$ preme Court. In Pringle, the ECJ was asked to assess the legality of the newly introduced ESM. ${ }^{106}$ The Irish Supreme Court decided to make a reference for a preliminary ruling to the ECJ, asking whether the ESM was compatible with several provisions of the EU Treaties. ${ }^{107}$ The ECJ, sitting in full with its

\footnotetext{
97 See e.g., Peter Praet, Member of the Executive Board of the ECB, Speech at the German Federal Ministry of Finance (Apr. 19, 2012), https://www.ecb.europa.eu/press/key/date/2012/html/sp120419. en.html.

98 HINAREJOS, supra note 25, at 20.

99 DYsON, supra note 92 , at 384.

$100 I d$. at 386.

101 Id. at 384, 387

102 For a more detailed reconstruction of the unfolding of the Euro crisis and the role played by the ECB, see HINAREJOS, supra note 25, at 21; see also infra text accompanying notes 126-130.

103 On changes caused by the response to the crisis in the EU, see THE CONSTITUTIONALIZATION OF European Budgetary ConstrainTs, (Maurice Adams, Federico Fabbrini \& P. Larouche eds., (2014); Mark Dawson \& Floris de Witte, Constitutional Balance in the EU After the Euro-Crisis, 76 MoD. L. REV. 817 (2013).

104 See Case C-62/14, Gauweiler v. Deutscher Bundestag, EU:C:2015:7; Case C-370/12, Pringle v. Gov't of Ireland, ECLI:EU:C:2012:756.

105 Pringle, ECLI:EU:C:2012:756, 92.

$106 I d$.

107 Id.
} 
27 judges — a rare event — rejected all challenges and upheld the ESM in all its aspects. ${ }^{108}$

For purposes of this article, only some of the aspects addressed in Pringle are directly relevant. First, the case signalled the new deference adopted by the ECJ in issues related to the economic and financial crises. ${ }^{109}$ While on other topics the ECJ has always been rather assertive, in this field it has shown a remarkable level of deference. ${ }^{110}$ Crucially, the ECJ adopted in this case a purposeful and teleological reading of the no-bail clause in Article 125 of the TFEU. ${ }^{111}$ According to the ECJ, this Article has two aims: first, to encourage prudent budgetary policy in the Member States by ensuring that they remain responsible to their creditors; ${ }^{112}$ and second, to safeguard the financial stability of the Euro area as a whole. ${ }^{113}$ The ECJ introduced a new rationale for the governance of the Eurozone, one which did not have any explicit recognition in the Treaties. ${ }^{114}$ In the case of the ESM, the instrument was necessary to safeguard the financial stability of the Eurozone, and because it was attached to conditionality, it was not in violation of the no bail-out clause. ${ }^{115}$

A second important point, which concerns the ECB more directly, is dictated by the use of EU institutions outside the context of EU law. ${ }^{116}$ The ESM and the Fiscal Treaty have been approved not as part of EU law, but as international treaties coming out of intergovernmental decisions. ${ }^{117}$ The Court concluded that the allocation of tasks to EU institutions outside the framework of EU law was not problematic, at least as long as it was affecting an area of exclusive EU competence. ${ }^{118}$ Note, incidentally, that this recognition may imply the non-applicability of the EU Charter of Fundamental Rights to actions taken by EU institutions outside of the framework of EU

\footnotetext{
$108 \quad$ Id. 10186.

109 Id.; Takis Tridimas \& Napoleon Xanthoulis, A Legal Analysis of the Gauweiler Case: Between Monetary Policy and Constitutional Conflict, 23 MAASTRICHT J. EUR. \& COMP. L. 17, 32-33 (2016) (discussing the impact of the Pringle decision on the later Gauweiler case).

110 See id. at 31 .

111 On the Court's legal reasoning in Pringle, see Paul Craig, Pringle: Legal Reasoning, Text, Purpose and Teleology, 20 MAASTRICHT J. EUR. \& COMP. L. 3, 7 (2013).

112 Pringle, ECLI:EU:C:2012:756, ๆ 135-36.

113 Id. $₫ 136$

114 See, e.g., Ciara Murphy, Pringle-The Unconstitutional Constitutional Amendment Conundrum, EUR. L. BLOG (Dec. 6 2012), http://europeanlawblog.eu/?p=1305.

115 Pringle, ECLI:EU:C:2012:756, 142.

$116 I d .993$.

117 Q\&A: EU Fiscal Treaty to Control Eurozone Budgets, BBC (Mar. 2, 2012), http://www. bbc.com/news/world-europe-16057252.

118 Pringle, ECLI:EU:C:2012:756, Фๆ 158-68.
} 
law. ${ }^{119}$ The ECB's function in the governance of the Euro would be sanctioned, from now on, as an exercise first in crisis management, for which no rules were foreseen, and then in policy making. ${ }^{120}$ In other words, the ECJ's purposeful reasoning in Pringle paved the way for the formal recognition of an informal transformation. ${ }^{121}$ The governance of the Eurozone would still be left in the hands of technocratic bodies, but now with an overtly discretionary and rather political function to perform. ${ }^{122}$ Once this transformation was publicly ratified by the ECJ, it was only a matter of time before a new challenge, concerning the changed nature of the EMU's and of the role of the ECB's would be presented to the ECJ.

\section{GAUWEILER: DOES PROPORTIONALITY TRUMP THE RULE OF LAW?}

The background which led to Gauweiler v. Deutscher Bundestag, ${ }^{123}$ the most important decision on the role of the ECB, must be quickly summarized for a proper understanding of both the major shift in the constitutional balance of the EU and of what is properly at stake in the case. In 2012, doubts about the future of the euro were still rampant and the cost of borrowing money for some Member States had increased alarmingly in the previous year, particularly in Spain, Italy, and Greece. ${ }^{124}$ In the middle of this crisis, the president of the ECB, Mario Draghi, announced that "the ECB is ready to do whatever it takes to preserve the euro," adding, famously, "[a]nd believe me, it will be enough." 125

One month later, at a press conference, after a meeting of the ECB's Governing Council, President Draghi announced to the public the decision to

119 Margot E. Salomon, Of Austerity, Human Rights and International Institutions, 21 EUR. L.J. 521, 534 (2015) ("One unresolved issue of key importance is the possibility that EU institutions could do outside of the EU that which they could not do within the EU-disregard the Charter of Fundamental Rights in the exercise of their tasks. The Court, for its part, left open whether the EU institutions-the EC and the ECB - can be bound by the Charter in relation to their conduct under the ESM.") (footnote omitted).

120 See Jörg Bibow, The Euro's Savior? Assessing the ECB's Crisis Management Performance and Potential for Crisis Resolution, 42 IMK STUDIES (Institut für Makroökonomie und Konjunkturforschung, Dusseldorf, Germany), June 2015, at 55-56, http://www.boeckler.de/pdf/ p_imk_study_42_2015.pdf.

121 See id. at 23-24.

122 See id.

123 Case C-62/14, Gauweiler v. Deutscher Bundestag, ECLI:EU:C:2015:400, http://eur-lex.europa.eu/legal-content/EN/TXT/PDF/?uri=CELEX:62014CJ0062\&from=EN.

124 See, e.g., Jack Ewing, The Euro Zone Crisis: A Primer, N.Y. TIMES: ECONOMIX (May 22, 2012), http://economix.blogs.nytimes.com/2012/05/22/the-euro-zone-crisis-a-primer.

125 Mario Draghi, President of the European Central Bank, Speech at the Global Investment Conference in London (July 26, 2012), https://www.ecb.europa.eu/press/key/date/2012/html/sp120726. en.html. 
conduct the OMT program and gave some details. ${ }^{126}$ In its statement, the ECB declared that it was ready to purchase secondary-market government bonds issued by Member States of the Eurozone, subject to certain conditions: first, states concerned had to be subject to financial assistance, by either the European Financial Stability Facility ("EFSF") or the ESM; second, no quantitative limits for the amount of purchases of these bonds were announced; third, the ECB would act in the same way as any private creditors and therefore would not benefit from a special status as public actor. ${ }^{127}$ Following the announcement, the volatility of the interest rates paced down, the OMT program has never been activated, and the program itself has now been overcome by a new project of "quantitative easing" defined as the Asset Purchase Program ("APP"), a staggering 60 billion euros per month program through which government bonds are purchased on secondary markets. ${ }^{128}$

It is this background through which the question about the legality of the OMT emerged and, extraordinarily, through which the first preliminary reference ever sent from the German Federal Constitutional Court ("FCC") was raised. The FCC basically asked the ECJ whether the ECB overstepped its powers relating primarily to monetary policy: did the ECB act ultra vires in venturing into economic policy? ${ }^{129}$ More specifically, the FCC, in its reference, raises the question whether the OMT program, rather than being a monetary policy measure under Article 18 protocol and Art. 119 TFEU, is in fact an economic policy measure, which would be outside the jurisdiction of the ECB. ${ }^{130}$

Predictably, both the Advocate General and the ECJ decided in favour of the legality of the OMT program. ${ }^{131}$ The unsurprising character of the decision is not solidly grounded in legal reasoning or in natural deference. After Pringle, one could foresee that the ECJ had bought into the narrative, which links the trajectory of the single currency to the survival of the EU as such:

126 See Press Conference, Mario Draghi, President of the European Central Bank, (Sept. 6, 2012), http://www.ecb.europa.eu/press/pressconf/2012/html/is120906.en.html.

127 Press Release, European Central Bank, Technical Features of Outright Monetary Transactions (Sept. 6, 2012), http://www.ecb.europa.eu/press/pr/date/2012/html/pr120906_1.en.html [hereinafter OMT Press Release].

128 Vestert Borger, Outright Monetary Transactions and the Stability Mandate of the ECB: Gauweiler, 53 COMMON. L REV. 139, 148 (2016) ("Until now the ECB has never had to use the OMT programme.”); Expanded Asset Purchase Programme, EUR. CENT. BANK, https://www.ecb.europa. eu/mopo/implement/omt/html/index.en.html (last visited Nov. 9, 2016).

129 Case C-62/14, Gauweiler v. Deutscher Bundestag, ECLI:EU:C:2015:400, ๆๆ 5-8, http://eurlex.europa.eu/legal-content/EN/TXT/PDF/?uri=CELEX:62014CJ0062\&from =EN.

$130 \quad I d . \rrbracket 10$.

131 Id. 127; Opinion of Advocate General Cruz-Villalón, Gauweiler v. Deutscher Bundestag, Case C-62/14, ECLI:EU:C:2015:7, q 263, http://eur-lex.europa.eu/legal-content/EN/TXT/PDF/?uri= CELEX:62014CC0062\&from=EN. 
no euro, no EU. ${ }^{132}$ The case also tested the boundaries of what is admissible as res judicada before the ECJ. ${ }^{133}$ In fact, the ECJ thought that it had jurisdiction over the communication of the ECB, which is something not automatically out of doubt. ${ }^{134}$ After all, no future binding legal act had been performed by the ECB and the communication in itself did not have a manifest legal nature. ${ }^{135}$ But the ECJ thought that in the context of regulation of monetary policy, the circulation of information matters and the ECB, as European agency, has the explicit legal obligation to communicate widely and transparently. ${ }^{136}$ The ECJ maintained that this would be enough to make the ECB communicative act legally reviewable under the same criteria of a formal act. $^{137}$

Beyond the jurisdictional question, there is a lot to be said about this decision. ${ }^{138}$ Gauweiler represents the most prominent case in the definition of the limits of judicial review of central banking. It is part and parcel of the sui generis nature of the European constitutional order that a nearly hypothetical question essentially of administrative law nature about the potential action of an independent agency might trigger such a heated confrontation between the German constitutional court and the ECJ. ${ }^{139}$ But, as shall be shown, it is also the certification of a transformation in the nature of the function of central banking. In light of the previous history of confrontations, this judicial dialogue has the potential of triggering an authentic constitutional conflict between the two most powerful European courts. ${ }^{140}$

Yet, this issue, as important as it is in the identification of the legal value of EU law (in the hierarchy of legal sources), won't be discussed in this article. The focus is rather on two other points: first, the transformation of the

132 Gauweiler, ECLI:EU:C:2015:400, ๆ 59-61 (noting that the EU would not survive if national courts could render different judgments on the validity of the ESM, thus potentially jeopardizing the Euro).

133 Id. ๆ 18-31. This is not the first time that the Court takes up this line of reasoning. In ERTA, the ECJ reviewed a Council position paper coordinating Member States in the negotiations for the conclusion of an international agreement which was subject to judicial review because it was capable of "derogating ... from the procedure laid down by the Treaty." Case C-22/70, Comm'n of the Eur. Cmtys. v. Council of the Eur. Cmtys., 1971 E.C.R. 263, - 54, http://eur-lex.europa.eu/legal-content/ENTXT/ $\mathrm{PDF} /$ ?uri $=\mathrm{CELEX}: 61970 \mathrm{CJ} 0022 \&$ from $=\mathrm{EN}$.

134 See Gauweiler, ECLI:EU:C:2015:400, ๆ甲 6, 121.

135 Id. 16 ; see also OMT Press Release, supra note 127.

136 Gauweiler, ECLI:EU:C:2015:400, ๆ 82-87.

137 Id. 9 甲 88-91.

138 For insightful comments on this seminal case see generally Federico Fabbrini, After the OMT Case: The Supremacy of EU Law as the Guarantee of the Equality of the Member States, 16 GER. L.J. 1003 (2015); Alicia Hinarejos, Case Note: Gauweiler and the Outright Monetary Transactions Programme: The Mandate of the European Central Bank and the Changing Nature of Economic and Monetary Union, 11 EUR. CONST. L. REV. 563 (2015).

139 Fabbrini, supra note 138, at 1004-05.

140 See Michael A. Wilkinson, The Euro Is Irreversible! . . Or is it?: On OMT, Austerity and the Threat of “Grexit,” 16 GER. L. J. 1049, 1050, 1072 (2015). 
structure of governance in the Eurozone; and second, the limited judicial capacity of holding the ECB to account for its policies.

The two aspects are sides of the same coin: the new policy-oriented governance of the Eurozone requires stronger forms of accountability and in particular of political responsibility. This two-fold argumentation is reflected in the structure of the ECJ's judgment. In fact, after having established that the press release of the Governing Council of the ECB was subject to judicial review, the ECJ engaged first with the legal basis of the ECB's action. ${ }^{141}$

The key provision here is Article 126 TFEU, which prohibits excessive government deficits. ${ }^{142}$ In the realm of public expenditures, the competence of the ECB is strictly circumscribed by the prohibition of monetary financing of Member State debt by means of direct purchase of government bonds. ${ }^{143}$ In an analysis of the distinction between economic and monetary policy, the Court held that "in order to determine whether a measure falls within the area of monetary policy" it was necessary to assess the objectives and the instrument used. ${ }^{144}$

According to the Court, the OMT program certainly fell within the scope of the ECB monetary policy. ${ }^{145}$ The core of the ECJ's argument revolves around the point made by the ECB itself: the OMT aimed "to safeguard both an appropriate monetary policy transmission and the singleness of the monetary policy." 146 The ECB based its argument for constructing an expanded role in its need to act to secure the monetary policy transmission mechanism by preventing financial fragmentation in the form of widely different interest rates in Member States: Appropriate "monetary policy transmission" cannot be granted in presence of massive spreads among national bonds. ${ }^{147}$ Concerning the instrument used, the ECB Statute granted to the ECB the power to conduct transactions on the secondary markets. While OMT may "to some extent, further the economic policy objectives" of adjustment programs, "such indirect effects do not mean that such a program must be treated as equivalent to an economic policy measure, since it is apparent from Articles 119(2) TFEU, 127(1) TFEU and 282(2) TFEU that, without prejudice to the objective of price stability, the ECSB is to support the general economic policies in the [EU]." 148

The Court reads the prohibition contained in Article 123 TFEU against the background of the conditionality imposed by ESFS or ESM programs. ${ }^{149}$

\footnotetext{
141 See Case C-62/14, Gauweiler v. Deutscher Bundestag, ECLI:EU:C:2015:400, Фศ 27-28, 31-33; Fabbrini, supra note 138, at 1007.

142 TFEU art. 126.

143 Id. art. 123.

144 Gauweiler, ECLI:EU:C:2015:400, 446.

$145 I d . \rrbracket 56$.

146 Id. $\uparrow 47$ (internal quotation marks omitted).

147 Id. 972 ; see also DYSON, supra note 92, at 385.

148 Gauweiler, ECLI:EU:C:2015:400, at 9 ๆ 58-59.

149 Id., at 4 (quoting OMT Press Release, supra note 127).
} 
Here, the shift is clear: what is essential in order to determine the legality of the ECB's OMT program is that it does not lessen the impetus of the Member States to follow a sound budgetary policy. ${ }^{150}$

A large part of the Court's reasoning is then devoted, in classic fashion, to proportionality review of the program. In accordance with the Advocate General's advice, ${ }^{151}$ the ECJ acknowledged that because the ECB is supposed "to make choices of a technical nature and to undertake forecasts and complex assessments, it must be allowed, in that context, a broad discretion." ${ }^{152}$ The question, at this stage, obviously concerns how to harness such discretion in a way which remains compatible with the rule of law. The ECJ suggests a procedural test of proportionality in order to check the legality of the ECB's discretion. ${ }^{153}$ As for what concerns the suitability step of proportionality review, the Court held that "it does not appear that that analysis of the economic situation of the euro area as at the date of the announcement of the program in question is vitiated by a manifest error of assessment." ${ }^{154}$ The point of technical expertise is again conjured up at this point:

[G]iven that questions of monetary policy are usually of a controversial nature and in view of the ESCB's broad discretion, nothing more can be required of the ESCB apart from that it uses its economic expertise and the necessary technical means at its disposal to carry out that analysis with all care and accuracy. ${ }^{155}$

As for the second step of proportionality review, the necessity of the OMT program, the ECJ ruled the action of the ECB did "not go manifestly beyond what is necessary to achieve those objectives." 156 The ECB had the expertise to decide if and when a bond-buying program may prove necessary in order to avoid the disruption of the monetary policy transmission. ${ }^{157}$ However, given that it is impossible to establish in advance how long will it take to support a Member State's bonds on the markets, ${ }^{158}$ it seems that the necessity of the program and the absence of possible alternatives have not been fully appreciated by the ECJ.

\footnotetext{
150 See id. $\mid 120$ ("The fact that the purchase of government bonds is conditional upon full compliance with the structural adjustment programs to which the Member States concerned are subject precludes the possibility of a program, such as that announced in the press release, acting as an incentive to those States to dispense with fiscal consolidation, relying on the financing opportunities to which the implementation of such a program could give rise.").

151 Opinion of Advocate General Cruz-Villalón, Gauweiler v. Deutscher Bundestag, Case C-62/14, ECLI:EU:C:2015:7, $\uparrow 111$.

152 Gauweiler, ECLI:EU:C:2015:400, 968.

$153 I d .966$.

$154 I d .974$.

155 Id. $\ 75$.

156 Id. ๆ 81.

157 See Gauweiler, ECLI:EU:C:2015:400, 89.

158 But see id. 87-88; Opinion of Advocate General Cruz-Villalón, Gauweiler v. Deutscher Bundestag, Case C-62/14, ECLI:EU:C:2015:7, 1779.
} 
Finally, the Court seems completely unconcerned that the ECB is involved both as monetary broker in its role as Europe's central bank and fiscal enforcer through its part in the Troika's adjustment programs. ${ }^{159}$ On this point, the ECJ ignored the Opinion of the Advocate General. ${ }^{160}$ According to the latter, the double role of the ECB as part of a supervising body within a framework for financial assistance and in its bond-buying role in the OMT program would blur the attribution of functions of the ECB. ${ }^{161}$ The Advocate General, in case of the activation of the OMT program, deemed necessary that the ECB ought to distance itself from the Troika immediately. ${ }^{162}$ However, the Court failed to mention this important point. As noted by a scholar, in this way

The ECB would thus come to wield enormous power over a Member State that found itself in a situation of requesting assistance - with the ECB then setting monetary policy as well as negotiating economic policy and monitoring compliance with adjustment programs to the level of detail where it is dictating the opening hours of bakeries. $^{163}$

In conclusion, the decision seems to grant a wide margin of discretion to the ECB when it comes to deciding monetary policies. As remarked by the Advocate General Cruz Villalón, to exercise this task the ECB has at its disposal technical expertise and access to crucial information which allows it to devise monetary policies. ${ }^{164}$ Coupled with an extensive use of proportionality analysis, such an approach gives a great margin of discretion to the ECB, given that no one can anticipate what will be necessary to do in order to stabilize the monetary transmission and hence to secure the singleness of the currency. ${ }^{165}$

The measure of discretion granted to the ECB is not only beyond the reach of substantive judicial review and the application of EU fundamental rights. ${ }^{166}$ It is so wide that it has assumed a political dimension, because it is capable of determining the trajectory of political aims in countries of the Eurozone (i.e., the debtor countries). ${ }^{167}$ In fact, the Governing Council of the

\footnotetext{
159 Wilkinson, supra note 140, at 1058.

160 Compare Opinion of Advocate General Cruz-Villalón, Gauweiler, ECLI:EU:C:2015:7, qథ14243 with Gauweiler, ECLI:EU:C:2015:400, $\uparrow \uparrow$ 58, 60; see also Wilkinson, supra note 140, at 1058.

161 Opinion of Advocate General Cruz-Villalón, Gauweiler, ECLI:EU:C:2015:7, $\uparrow \uparrow ~ 248-50$.

162 Id. 150 . The Troika is the triad of institutions (the ECB, the International Monetary Fund, the European Commission) that are in charge of overseeing the application of austerity programs.

163 Wilkinson, supra note 140, at 1058.

164 Opinion of Advocate General Cruz-Villalón, Gauweiler, ECLI:EU:C:2015:7, ๆๆ 110-11, 151.

165 Id. 9 1 $186-87$.

166 See Case C-370/12, Pringle v. Gov’t of Ireland, ECLI:EU:2012:756, ๑థ 178-82.

167 See Gauweiler, ECLI:EU:C:2015:400, ๆๆ 76, 78, 89; Smits, supra note 52, at 1175.
} 
ECB is not only entitled to decide interest rates, but actually to steer the political trajectory of monetary policies and to oversee fiscal and financial capacities of debtor Member States. ${ }^{168}$

In a nutshell, the ECJ has rubberstamped the entrenchment of a political role for an independent agency such as the ECB. What is possibly the most independent central bank in the world has now become a political player in the Eurozone. It is fair to note that it was not possible to demand from the ECJ an extremely activist attitude because " $[t]$ here is indeed reason to exercise a degree of judicial restraint when scrutinising the [ECB]'s policy decisions, given its nature as an expert body and the independence granted to it by the Treaties." ${ }^{169}$ However, remaining within a strict understanding of its competences, the ECJ could have openly discussed whether the independence and the expertise of the ECB are tainted by its participation under different guises in the new economic governance or applied a more demanding proportionality test.

\section{THE LiMits OF LEGAL ACCOUNTABILITY}

Pringle and Gauweiler show that there has been a shift in the governance of the single euro currency. The question of the respect of competences by the ECB's Press Release was addressed starting from this assumption, which remains unscrutinised and taken for granted as if it were not problematic for the principle of the rule of law. Even the claim that the measures adopted to cope with the Euro crisis are based on the logic of the emergency is never fully questioned, whereas it has become evident, at least by now, that the bulk of the new economic governance of the Euro and of the new policies adopted by the ECB and the Eurogroup are here to stay. ${ }^{170}$

Whether the rule of law had been violated required a stricter scrutiny than the one applied by the ECJ. These limits of judicial review are a consequence of using a flattening and weak device like a procedural understanding of the proportionality test for cases where even the first step of proportionality analysis, the legitimacy of the aim of the measure under review, deserved a deeper analysis than what is usually granted..$^{171}$

The ECJ has avoided both confronting the political implications of monetary policy in the suboptimal currency and facing the consequences deriving

168 Eur. CENT. BANK, GOVERnING COUNCIL (2016), https://www.ecb.europa.eu/ecb/orga/decisions/govc/html/index.en.html; Heisbourg, supra note 40, at 28-29.

169 Hinarejos, supra note 138, at 575 (footnote omitted_.

170 Cf. Jonathan White, Emergency Europe, 63 POL. STUD. 300, 301 (2013).

171 For a reconstruction of the different forms of proportionality review, usually determined by the relevant constitutional culture, see AHARON BARAK, PROPORTIONALITY: CONSTITUTIONAL RIGHTS AND THEIR LIMITATIONS (2012); JACCO BOMHOFF, BALANCING CONSTITUTIONAL RIGHTS: THE ORIGINS AND MEANings OF POSTWAR LEgAL Discourse (2013); and, in the European context, the classic ROBERT AleXY, A THEORY OF FundAMENTAL Rights (Julian Rivers, trans., 2010). 
from the new constitutional function granted to the ECB. ${ }^{172}$ Some commentators have praised the new approach adopted by the ECJ, mostly in light of its prudential stance and the creativity of its reasoning. ${ }^{173}$ But, as it has been remarked, while the ECJ has played a crucial role in shaping European integration, "in relation to post-crisis developments that have affected the nature of EMU deeply ... the Court has tended to take a back seat to the political, often intergovernmental, process." ${ }^{174}$ One wonders whether such an extreme deferential attitude was necessary and what will be the consequences.

It is clear, however, that the twist given to legal accountability of the ECB by the Court's case law has by now proven to be largely insufficient. The failures of holding the ECB accountable and in signalling to the other European institutions - and in this way to the wider public - certain potential issues arising out of the OMT litigation represent one of the weakest moments in the ECJ's history. This decision is a missed opportunity for flagging questions concerning the constitutional function exercised de facto by the $\mathrm{ECB}$, at least in the Eurozone. The rule of law and the political quality of central banking decisions have been sacrificed to the altar of the single currency. Once assumed that this bargain may be effective, and this is far from being certain, it will remain to be seen whether it is worthwhile. ${ }^{175}$

172 Sofiya Kartalova, In the ECJ We Trust: The Authority of EU Law in the Context of Constitutional Conflict, 2011 INTERSTATE J. OF INT'L AFF. 28, 31 (2011).

173 See, e.g., Craig, supra note 111, at 206.

174 HinAREJOS, supra note 25, at 121.

175 See generally Ben Crum, Saving the Euro at the Cost of Democracy?, 51 J. OF COMMON MKT. STUD. 614 (2013). 